\title{
Efficacy of Organic Manures and Bio-fertilizers on Yield Attributes and Yield of Okra var. Chameli
}

\author{
Rukshana Bano", A.K. Soni, Jai Singh, S.P. Singh and Arun Kumar Mahawar \\ Department of Horticulture, S.K.N. College of Agriculture, Jobner - 303 329, Jaipur, \\ Rajasthan, India \\ *Corresponding author
}

\begin{abstract}
A B S T R A C T
Keywords

Okra, Organic manures, Biofertilizers, Yield attributes and yield

Article Info

\section{Accepted:}

26 July 2018

Available Online:

10 September 2018

A field experiment was conducted to study the 'Efficacy of organic manures and biofertilizers on yield attributes and yield of okra var. Chameli' during rainy season 2016-17 at Horticulture Farm, S.K.N. College of Agriculture, Jobner (Jaipur) with consisted of 16 treatments combinations viz., organic manures (Control, FYM, Poultry Manure and Vermicompost) and bio-fertilizers (Control, PSB, VAM and Azotobacter) tested in randomized block design with three replications. results shows that the application of vermicompost @ $8 \mathrm{t} \mathrm{ha}^{-1}$ and Azotobacter alone significantly increased the number of fruit plant ${ }^{-1}$, fruit weight $(\mathrm{g})$, fruit length $(\mathrm{cm})$ fruit yield plant ${ }^{-1}(\mathrm{~g})$, fruit yield $\operatorname{plot}^{-1}(\mathrm{~kg})$ and fruit yield hectare ${ }^{-1}$ (q) as compared to control, FYM and poultry manure. The combined application of vermicompost @ $8 \mathrm{t} \mathrm{ha}^{-1}+$ Azotobacter as seed inoculation proved to be most superior treatment combination in terms of fruit weight $(\mathrm{g})$, fruit yield plant $^{-1}(\mathrm{~g})$, fruit yield $\operatorname{plot}^{-1}(\mathrm{~kg})$ and fruit yield hectare ${ }^{-1}(\mathrm{q})$.
\end{abstract}

\section{Introduction}

Okra [Abelmoschus esculentus (L.) Moench] plant is erect, herbaceous annual green and belongs to family malvaceae. It is indigenous to tropical Africa and grown throughout the tropics and subtropics. It can be fried or cooked with necessary ingredients. The tender fruit can be cut into small pieces, boiled and served with soup. Matured fruits and stem containing crude fibres are used in the paper industry. The roots and stems are used for clearing cane juice in preparation of 'gur'. High iodine content of fruits helps to control goiter. Okra is said to be very useful against genito-urinary disorders, spermatorrhoea and chronic dysentery (Nadkarni, 1927). The oil is used in soap and cosmetic industry, while protein is used for fortified feed preparation. The crushed seed is fed to cattle for higher milk production and the fibre is utilized in jute textile and paper industry. Okra is grown on 0.14 million hectares with the production of 0.88 million tonnes and in the India, it is grown on 533 thousand hectare with the production of 6346('000 MT) (Anonymous, 2015).

In India, the mixed farming system with livestock raising is an integral part of crop 
production of Indian farmers. Farm yard manure is rich in nutrients basically using cow dung, cow urine, waste straw and other dairy wastes. The organic manure FYM not only provides nutrient to the plant but also improves the soil texture by binding effect of soil aggregates. Organic manure increases cation exchange capacity, water holding capacity and phosphate availability of the soil beside improving the fertilizer use efficiency and microbial population of soil, it reduces nitrogen loses due to slow release of nutrients (Tadesse et al., 2013). Vermicompost is a slow nutrient releasing organic manure which have most of the macro as well as micro nutrients in chelated form and fulfill the nutrient requirement of plant for longer period.

Vermicompost is being a stable fine granular organic matter, when added to soil, it loosens the soil and improves the passage to the entry of air. The soil enriched with vermicompost provides additional substances that are not found in chemical fertilizers. Vermicompost is made up primarily of $\mathrm{C}, \mathrm{H}$ and $\mathrm{O}$ and contains nutrients such as $\mathrm{NO}_{3}, \mathrm{PO}_{4}, \mathrm{Ca}, \mathrm{K}, \mathrm{Mg}, \mathrm{S}$ and micronutrients which exhibit similar effects on plant growth and yield as inorganic fertilizers applied to soil (Singh et al., 2008). Poultry manure is a valuable fertilizer and can serve as a suitable alternate to chemical fertilizer. Poultry manure application registered over 53 per cent increases of $\mathrm{N}$ level in the soil, form 0.09 per cent to 0.14 per cent and exchangeable cations increase with manure application (Boateng et al., 2006). In agriculture, the main reasons for applying poultry manure include the organic amendment of the soil and the provision of nutrients to crops (Warren et al., 2006). Poultry manure was readily available and in the best form for easy absorption by the plant roots, hence there was a boost in the morphological growth of the plant (Onwu et al., 2014).
Bio-fertilizers liberate growth promoting substances and vitamins and help to maintain soil fertility. Phosphate solubilizing Bacteria (PSB) significantly helps in the release of this insoluble inorganic phosphate and makes it available to the plants. PSB are a group of beneficial bacteria capable of hydrolysing organic and inorganic phosphorus from insoluble compounds. P-solubilization ability of the microorganisms is considered to be one of the most important traits associated with plant phosphate nutrition. It is generally accepted that the mechanism of mineral phosphate solubilization by PSB strains is associated with the release of low molecular weight organic acids through which their hydroxyl and carboxyl groups chelate the cations bound to phosphate, thereby converting it into soluble forms. In addition, some PSB produce phosphatase like phytase that hydrolyse organic forms of phosphate compounds efficiently. PSB have been introduced to agricultural community as phosphate 'Biofertilizer' (Gupta et al., 2014). Mycorrhizae are the root-symbionts which obtain their nutrients from the plant and provide mineral elements like $\mathrm{N}, \mathrm{P}, \mathrm{K}, \mathrm{Ca}, \mathrm{S}$ and $\mathrm{Zn}$ to the host plant.

This review is an attempt to explore the suppressing abilities of Arbuscular Mycorrhizal Fungi (AMF) against soil borne pathogens (root feeding nematodes and fungi), infecting various crops. AMF to increase the productivity of cereal crops, fruits and vegetable crops (Abbasi et al., 2015). Azotobacter has beneficial effects on crop growth and yield through, biosynthesis of biologically active substances, stimulation of rhizospheric microbes, producing phyopathogenic inhibitors. Modification of nutrient uptake and ultimately boosting biological nitrogen fixation. The presence of Azotobacter sp. in soils has beneficial effects on plants, but the abundance of these bacteria is related to many factors, soil physico- 
chemical (e.g. organic matter, $\mathrm{pH}$, temperature, soil moisture) and microbiological properties (Jnawali et al., 2015).

\section{Materials and Methods}

A field experiment entitled 'Efficacy of organic manures and bio-fertilizers on yield attributes and yield of okra [Abelmoschus esculentus (L.) Moench]' was conducted at Horticulture Farm, S.K.N. College of Agriculture, Jobner in randomized block design comprising of 16 treatment combinations viz., organic manures (Control, FYM, Poultry Manure and Vermicompost) and bio-fertilizers (Control, PSB, VAM and Azotobacter) during Kharif season 2016.

The treatments were randomly allocated to different plots using random number table of Fisher and Yates (1963). Healthy seeds of variety Chameli were dibbled $2 \mathrm{~cm}$ deep maintaining uniform distance of $45 \times 60 \mathrm{~cm}$ in two successive hills. Fym and Poultry Manure were applied in the beds as per treatments and was thoroughly incorporated in to the soil before sowing and at the time of seed sowing according to RDF of okra (102:60:60 NPK). We calculated FYM @ $24 \mathrm{t} \mathrm{ha}^{-1}$, Poultry Manure@6 t ha ${ }^{-1}$ and Vermicompost@8t $\mathrm{ha}^{-1}$ was supplied about 3-4 cm deep at the time of sowing. Application of biofertilizers was done as per treatment Azotobacter $(200 \mathrm{ml}$ ha $^{-1}$ ) as seed treatment. 2-3 $\mathrm{ml}$ Azotobacter in Liquid form was mixed in one litre of water. Then seeds are soaked in this solution for 25 minutes.

$P S B$ also applied as seed treatment @ 5g/kg seed for this $125 \mathrm{~g}$ of Jaggery was mixed in one litre of boiled water. Appropriate quantity $(2 \mathrm{~g})$ of was poured in Jaggery solution separately and stirred well. The seeds were allowed to air dry in shade. VAM @ $15 \mathrm{~kg} \mathrm{ha}^{-1}$ applied as soil application.

\section{Statistical analysis}

To test the significance of variance in the data obtained from the various yield attributes and yield the technique of analysis of variance was adopted as suggested by Fisher and Yates (1963) for randomized block design. Significance of difference in the treatment effect was tested through ' $F$ ' test at 5 percent level of significance and CD (critical difference) was calculated, wherever the results found significant.

\section{Results and Discussion}

\section{Efficacy of organic manures on yield attributes}

The data presented in Table 1 and depicted in Figure 1 showed that number of fruits plant ${ }^{-1}$, fruit weight $(\mathrm{g})$ and fruit length $(15.41 \mathrm{~cm})$ significantly increased under organic manures.

The maximum number of fruits plant $^{-1}$ (26.04), fruit weight $(15.29 \mathrm{~g})$ and fruit length $(15.41 \mathrm{~cm})$ were recorded under vermicompost $\left(\mathrm{M}_{3}\right)$, while minimum number of fruits plant ${ }^{-1}$ (16.55), fruit weight (12.08 g) and fruit length were recorded under control.

The magnitude increase with vermicompost were found to be in number of fruits plant ${ }^{-1}$ (57.34, 24.65 and 10.58), fruit weight (26.63, 15.20 and 9.25) and fruit length (54.59, 33.04 and 13.59) per cent more as control, FYM and poultry manure, respectively.

The beneficial effect of vermicompost on yield and yield attributes might be attributed to its ability to sustain availability of nutrient throughout the growing season. The increased balanced $\mathrm{C}$ : $\mathrm{N}$ ratio might have increased the synthesis of carbohydrates with ultimate improvement in yield and yield attributes (Kondappa et al., 2009; Sharma et al., 2010 and Yadav and Yadav, 2010). 
Fig.1 Efficacy of organic manures and bio-fertilizers on number of fruits plant ${ }^{-1}$, fruit weight $(\mathrm{g})$ and fruit length $(\mathrm{cm})$

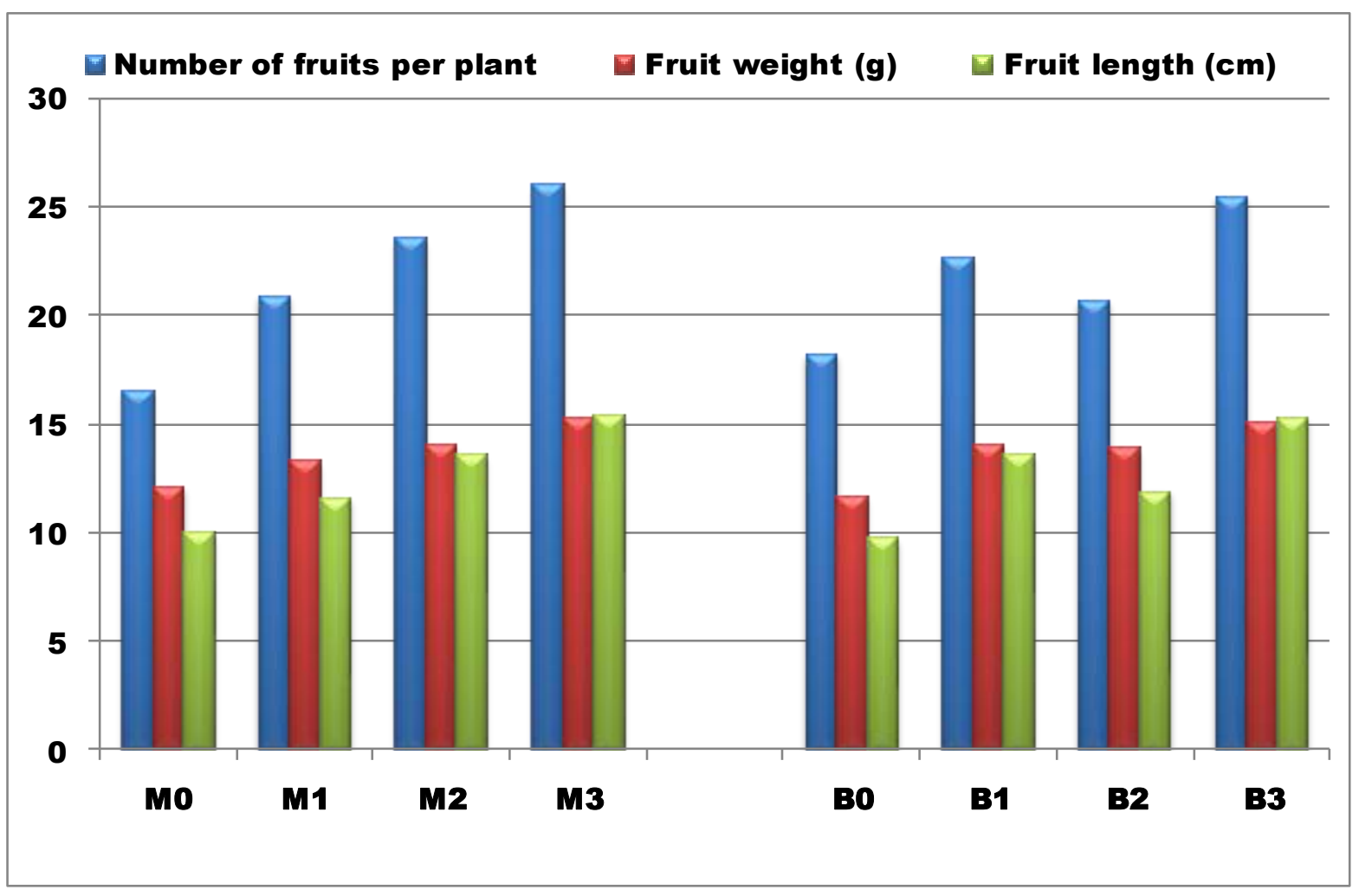

Fig.2 Efficacy of organic manures and bio-fertilizers on yield ha ${ }^{-1}(q)$

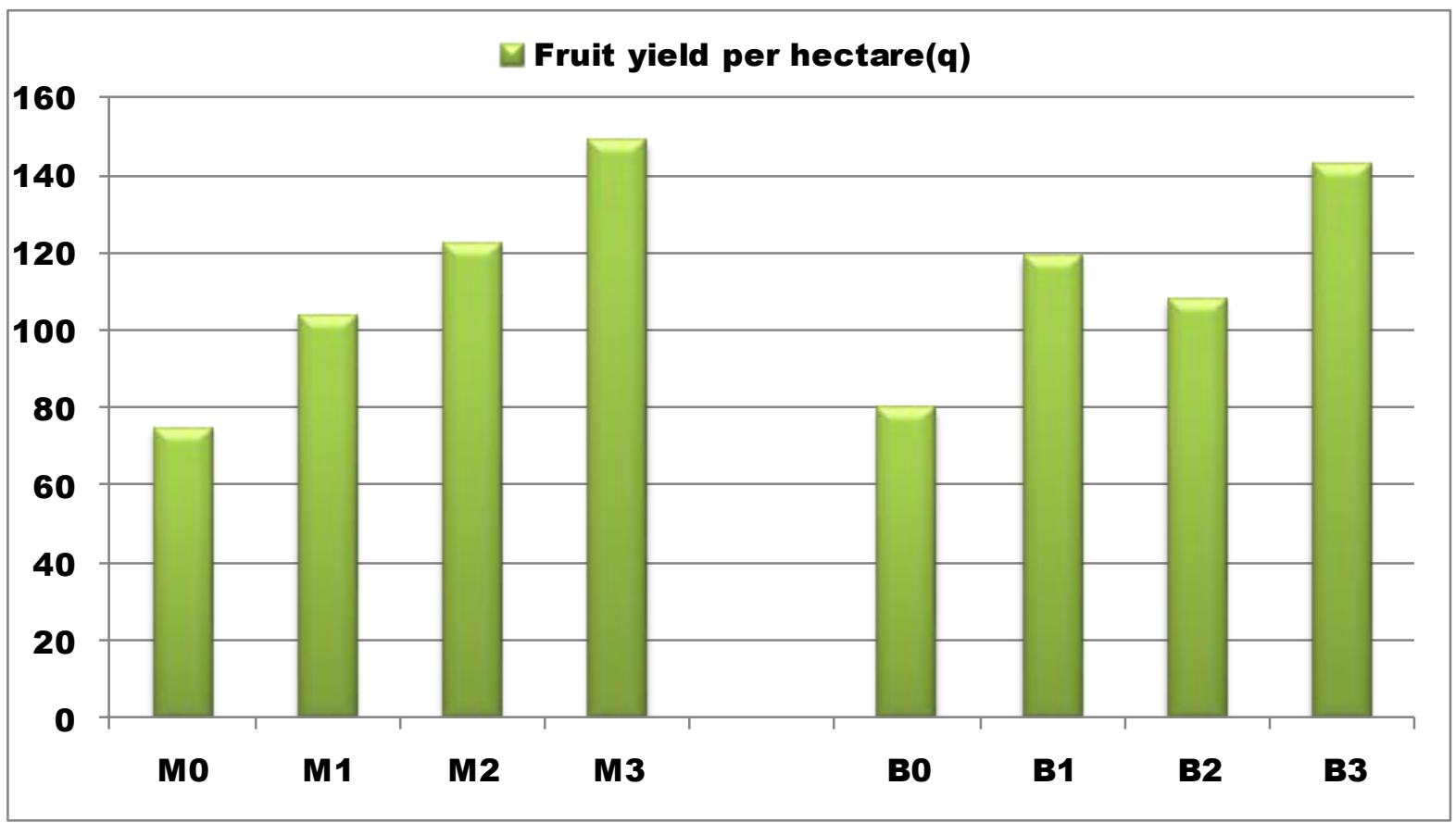


Table.1 Efficacy of organic manures and bio-fertilizers on yield and yield attributes of okra

\begin{tabular}{|c|c|c|c|c|c|c|c|c|}
\hline $\begin{array}{l}\text { S. } \\
\text { No. }\end{array}$ & Treatments & $\begin{array}{l}\text { Number of } \\
\text { fruits plant }^{-1}\end{array}$ & $\begin{array}{c}\text { Fruit } \\
\text { weight }\end{array}$ & $\begin{array}{l}\text { Fruit } \\
\text { length }\end{array}$ & $\begin{array}{l}\text { Fruit yield } \\
\text { plant }^{-1}\end{array}$ & $\begin{array}{l}\text { Fruit yield } \\
\text { plot }^{-1}\end{array}$ & $\begin{array}{c}\text { Fruit yield } \\
\qquad \mathbf{h a}^{-1}\end{array}$ & $\begin{array}{c}\text { Yield } \\
\text { picking }^{-1}\end{array}$ \\
\hline \multicolumn{9}{|c|}{ A. Organic manures } \\
\hline 1. & Control $\left(\mathbf{M}_{0}\right)$ & 16.55 & 12.08 & 9.97 & 202.00 & 3.23 & 74.81 & 3.30 \\
\hline 2. & FYM @24 tha' ${ }^{-1}\left(M_{1}\right)$ & 20.89 & 13.27 & 11.58 & 280.99 & 4.50 & 104.07 & 4.71 \\
\hline 4. & $\begin{array}{l}\text { Vermicompost @ } 8 \mathbf{t} \mathbf{h a}^{-1} \\
\left(\mathbf{M}_{3}\right)\end{array}$ & 26.04 & 15.29 & 15.41 & 402.10 & 6.43 & 148.93 & 6.81 \\
\hline 1. & Control $\left(\mathbf{B}_{0}\right)$ & 18.20 & 11.69 & 9.75 & 216.01 & 3.46 & 80.00 & 3.88 \\
\hline 2. & $\operatorname{PSB}\left(\mathbf{B}_{1}\right)$ & 22.65 & 14.00 & 13.59 & 321.70 & 5.15 & 119.15 & 5.39 \\
\hline 3. & $\operatorname{VAM}\left(\mathbf{B}_{2}\right)$ & 20.69 & 13.88 & 11.90 & 291.48 & 4.66 & 107.95 & 4.69 \\
\hline 4. & Azotobacter $\left(\mathbf{B}_{3}\right)$ & 25.48 & 15.07 & 15.29 & 386.45 & 6.18 & 143.13 & 6.68 \\
\hline & S.Em. \pm & 0.51 & 0.28 & 0.35 & 6.45 & 0.11 & 2.52 & 0.12 \\
\hline & $\mathrm{CD}(\mathrm{P}=\mathbf{0 . 0 5})$ & 1.48 & 0.81 & 1.02 & 18.63 & 0.31 & 7.27 & 0.33 \\
\hline
\end{tabular}




\section{Efficacy of organic manures on yield}

Data regarding to fruit yield in okra are given Table 1 and depicted in Figure 2. The fruit yield plant ${ }^{-1}$, plot $^{-1}$, ha $^{-1}$ and picking ${ }^{-1}$ were significantly influenced by different organic manures. The maximum fruit yield plant ${ }^{-1}$ $(402.10 \mathrm{~g}), \operatorname{plot}^{-1}(6.43 \mathrm{~kg}), \mathrm{ha}^{-1}(148.93 \mathrm{q})$ and picking ${ }^{-1}(6.81 \mathrm{~kg})$ were recorded under vermicompost followed by poultry manure $(330.55 \mathrm{~g})$ and FYM (280.99 g) and minimum under control $(202.00 \mathrm{~g}, 3.23 \mathrm{~kg}, 74.81 \mathrm{q}$ and $3.30 \mathrm{~kg}$ ). The per cent increase in fruit yield plant $^{-1}$ (99.06, 43.10 and 21.64), plot $^{-1}$ (99.05, 43.10 and 21.64) $\mathrm{ha}^{-1},(99.05,43.10$ and 21.64) and picking ${ }^{-1}(106.36,44.62$ and 17.01) with vermicompost $\left(\mathrm{M}_{3}\right)$ were found to be higher over $\mathrm{M}_{0}, \mathrm{M}_{1}$ and $\mathrm{M}_{2}$, respectively. The increased yield attributes and yield with poultry manure might be because of rapid availability and utilization of nitrogen for various internal plant processes for carbohydrates production. Later on these carbohydrates undergo hydrolysis and get converted in to reproductive sugars which ultimately helped in increasing yield. These results are in accordance with the findings of Naidu et al., (2002) and Meerabai et al., (2007).

\section{Efficacy of bio-fertilizers on yield attributes}

A critical view of data (Table 1 and depicted in Fig. 1) revealed that application of Azotobacter produced significantly maximum number of fruits plant ${ }^{-1}$ (25.48), fruit weight $(15.07 \mathrm{~g})$ and fruit length $(15.29 \mathrm{~cm})$, which was found to be significantly superior over treatment control, $P S B$ and VAM. The per cent increase with Azotobacter found to be in number of fruits plant ${ }^{-1}(39.99,12.51$ and 23.14), fruit weight (28.83, 7.64 and 8.55$)$ and fruit length $(56.85,12.45$ and 28.45) per cent more over control, $P S B$ and VAM, respectively. Azotobacter has beneficial effects on crop growth and yield through, biosynthesis of biologically active substances, stimulation of rhizospheric microbes, producing phyopathogenic inhibitors. The presence of Azotobacter sp. in soils has beneficial effects on plants, but the abundance of these bacteria is related to many factors, soil physico-chemical (e.g. organic matter, $\mathrm{pH}$, temperature, soil moisture) and microbiological properties. Its abundance varies as per the depth of the soil profile. Azotobacter is much more abundant in the rhizosphere of plants than in the surrounding soil and that this abundance depends on the crop species (Jnawali et al., 2015).

\section{Efficacy of bio-fertilizers on yield}

Application of different bio-fertilizers significantly influenced increased the fruit yield plant ${ }^{-1}$, plot $^{-1}$, ha $^{-1}$ and picking ${ }^{-1}$ (Table 1 and Fig. 2). The maximum fruit yield plant ${ }^{-1}$ $(386.45 \mathrm{~g}), \operatorname{plot}^{-1}(6.18 \mathrm{~kg}), \mathrm{ha}^{-1}(143.13 \mathrm{q})$ and picking $^{-1}(6.68 \mathrm{~kg})$ obtained under treatment i.e. $\mathrm{B}_{3}$, while minimum fruit yield $(216.01 \mathrm{~g}, 3.46 \mathrm{~kg}, 80 \mathrm{q}$ and $3.88 \mathrm{~kg}$ ) was recorded under control. The per cent increase with Azotobacter found to be in fruit yield plant $^{-1}$, plot $^{-1}, \mathrm{ha}^{-1}$ (78.90, 20.12 and 32.58) and picking $^{-1}$ (72.23, 14.08 and 42.47) per cent more over $\mathrm{B}_{0}, \mathrm{~B}_{1}$ and $\mathrm{B}_{2}$, respectively.

The improvement in yield characters in okra with inoculation of $P S B$ is due to solubilization and increased availability of $P$ from insoluble or otherwise fixed phosphorus for its plant availability (Sahu et al., 2014). The beneficial effects of $P S B$ along with other nutrients increased yield of crop might have resulted due to higher rate in partitioning of different reproductive structure and yield attributes which might have ultimately in turned to higher yield of the crop (Bairwa et al., 2009). VAM inoculation in soil also significantly plays an important role in $\mathrm{P}$ cycling mobilization and uptake by plants, 
greater root extension, higher nutrient uptake, higher photosynthesis and balanced portioning are the main factor of significant increase in yield attributes and yield (Sidhya et al., 2015).

It is also not feasible to make available the required amount of $\mathrm{N}$ to the plants through vermicompost alone hence, an integration of vermicompost and seed inoculation by Azotobacter may be one of the better options to maintain soil fertility and sustain crop productivity.

\section{References}

Abbasi, Hisamuddin, Akhtar, A. and Sharf, R. 2015. Vesicular Arbuscular Mycorrhizal (VAM) fungi: a tool for sustainable agriculture. American Journal of Plant Nutrition and Fertilization Technology, 5 (2): 40-49.

Anonymous, 2015. Indian Horticulture Database, National Horticultural Board, Gurgaon. pp 10.

Bairwa, H.L., Shukla, A.K., Mahawer, L.N., Kaushik, R.A., Shukla, K.B. and Ameta, K.D. 2009. Response of integrated nutrient management on yield, quality and physico-chemical characteristics of okra cv. Arka Anamika. Indian Journal of Horticulture, 66(3): 310-314.

Boateng, S., Zickermann, A.J. and Kornaharens, M. 2006. Effect of poultry manure on growth and yield of maize. West Africa Journal of Applied Ecology, 9:1-11.

Fisher, R.A. and Yates, F. 1963. Statistical Tables. Oliver and Boyd, Edinburgh, London.

Gupta, G. N., Srivastava, S., Khare, S. K. and Prakash, V. 2014. Role of phosphate solubilizing bacteria in crop growth and disease management. Journal of Pure and Applied Microbiology, 8(1): 461-
474.

Jnawali, A. D., Ojha, R. B. and Marahatta, S. 2015. Role of Azotobacter in Soil Fertility and Sustainability. Advances in Plants \& Agriculture Research, 2(6): 69.

Kondappa, D., Radder, B.M., Patil, P.L., Hebsur, N.S. and Alagundagi, S.C. 2009. Effect of integrated nutrient management on growth, yield and economics of chilli (cv. Byadgi Dabbi) in a vertisol. Karnataka Journal of Agricultural Sciences, 22: 438.440.

Meerabai, M., Jayachandran, B. K. and Asha, K.R. 2007. Biofarming in bitter gourd (Momordica charantia L.). Acta Horticulturae, 752:349-352.

Nadkarni, K.M. 1927. Indian meteria medica. Vol-I, Bombay Popular Prakashan, second edition, reprint 1995,595.

Naidu, A.K., Kushwah, S.S. and Dwivedi, Y.C. 2002. Influence of organic manure, chemical and bio fertilizer on growth, yield and economics of brinjal. South Indian Horticulture, 50(7): 370376.

Onwu, A. C., Abubakar, J. R. and Unah, P. O. 2014. Effect of poultry manure on growth, yield of okra and soil properties in Makurdi, North Central Nigeria. International Journal of Agricultural and Food Science.

Sahu, A.K., Kumar S. and Maji S. 2014. Effect of biofertilizers and inorganic fertilizers on vegetative growth and yield of okra [Abelmoschus esculentus (L.) Moench]. International Journal of Agricultural Sciences, Volume 10: 558561.

Sharma, T.R., Pandey, A.K., Updhyaya, S.D. and Agrawal, S.B. 2010. Effect of vermicompost on yield and quality of kharif season okra [Abelmoschus esculentus (L.) Moench]. Vegetable Science, 37(1-2): 181-183

Sidhya, P., Pandit, M. K., Bairagi, S. and 
Shyamal, M. M. 2015. Effect of mycorrhizal inoculation, organic manure and inorganic fertilizers on growth and yield of okra [Abelmoschus esculentus (L.) Moench]. Journal Crop and Weed, 11(Special Issue): 10-13.

Singh, R., Sharma, R., Satyendra, K., Gupta, R. and Patil, R. 2008. Vermicompost substitution influence growth, physiological disorder fruit yield and quality of Strawberry [Fragaria $x$ ananassa (Duch)]. Bioresource Technology, 99:8502- 8511.

Tadesse, T., Dechassa, N., Bayu, W. and Gebeyehu, S. 2013. Effects of Farmyard Manure and Inorganic Fertilizer
Application on Soil Physico-Chemical Properties and Nutrient Balance in Rain-Fed Lowland Rice Ecosystem. American Journal of Plant Sciences, 4: 309-316

Warren, J.G., Phillips, S.B., Mullins, G.L., Keahey, D. and Penn C.J. 2006. Environmental and production consequences of using alum amended poultry litter as a nutrient source for corn. Journal of Environmental Quality, 35: 172-182.

Yadav, S.S. and Yadav, N. 2010. Effect of integrated nutrient management on yield of okra in zaid crop. Bhartiya Krishi Anusandhan Patrika, 25: 2-4.

\section{How to cite this article:}

Rukshana Bano, A.K. Soni, Jai Singh, S.P. Singh and Arun Kumar Mahawar. 2018. Efficacy of Organic Manures and Bio-fertilizers on Yield Attributes and Yield of Okra var. Chameli. Int.J.Curr.Microbiol.App.Sci. 7(09): 3668-3675. doi: https://doi.org/10.20546/ijcmas.2018.709.456 